\title{
Anatomical and Palynological Investigations on Rubia tinctorum L. (Rubieae, Rubiaceae) from the Aegean Region of Turkey
}

\author{
Nurettin ARI ${ }^{*}$, Ahmet KAHRAMAN² \\ ${ }^{1}$ Department of Molecular Biology and Genetics, Institute of Natural and Applied Sciences, Uşak University, 64200 Uşak, Turkey. \\ 2 Department of Biology, Faculty of Arts and Sciences, Uşak University, 64200 Uşak, Turkey. \\ ORCID ID: Nurettin ARI: https://orcid.org/0000-0002-1479-8960; Ahmet KAHRAMAN: https://orcid.org/0000-0002-9344-1993
}

\begin{abstract}
Received: 07.01 .2020
Accepted: 08.01 .2020

Published online: 28.01 .2020

Issue published: 29.06 .2020

Abstract: The genus Rubia L. includes valuable species in terms of important agricultural, industrial, and pharmacological characteristics. Red dye obtained from the roots of Rubia tinctorum L., naturally found in the flora of Turkey and known as common madder, has been used as the source of a natural dye since ancient times. In this work, a preliminary report is given on anatomical and palynological traits of $R$. tinctorum distributed in the Aegean Region of Turkey examined by light and scanning electron microscopy. In the root anatomy, the cortex composed of multilayered parenchyma cells, the vascular tissue organized in collateral vascular bundles, 1(-2)-rowed ray cells, and the pith with a cavity at the center are observed. In the leaf anatomy, the bifacial and amphistomatic leaf, the dorsiventral mesophyll with one layer of columnar palisade parenchyma cells and a few layers of irregularly organized spongy parenchyma cells, and the midrib with a large collateral vascular bundle surrounded by parenchymatous bundle sheath cells are recognized. Pollen grains are shed as monads, small, mostly spheroidal in equatorial view, generally hexacolpate and have a microechinate-perforate exine ornamentation.
\end{abstract}

Keywords: Rubia, vegetative anatomy, pollen morphology, microscopy technique.

\section{Türkiye'nin Ege Bölgesinden Rubia tinctorum L. (Rubieae, Rubiaceae) Üzerine Anatomik ve Palinolojik Araştırmalar}

\begin{abstract}
Öz: Rubia L. cinsi tarımsal, endüstriyel ve farmakolojik açıdan önemli türleri içermektedir. Türkiye florasında doğal olarak bulunan ve kızılboya olarak bilinen Rubia tinctorum L. eski tarihlerden beri köklerinden elde edilen kökboyası ile doğal boya kaynağı olarak kullanılmaktadır. Bu çalışmada, Türkiye' nin Ege Bölgesi'nde yayılış gösteren $R$. tinctorum'un ışık ve taramalı elektron mikroskobu ile incelenen anatomik and palinolojik özellikleri üzerine bir ön değerlendirme raporu verilir. Kök anatomisinde, çok sıralı parankima hücrelerinden meydana gelen korteks, kollateral iletim demetlerinden oluşan iletim doku, 1(-2) sıralı ışın hücreleri ve merkezinde bir boşluk bulunan öz gözlemlenmektedir. Yaprak ayası anatomisi incelendiğinde, bifasiyal ve amfistomatik tipte yaprak, 1 sıralı silindir şeklinde palizat parankiması ile birkaç sıralı düzensiz dizilmiş sünger parankimasından oluşan dosiventral tipte mezofil ve parankimatik demet kını hücreleri tarafından çevrelenen büyük kollateral bir iletim demetine sahip orta damar bulunmaktadır. Polen tanecikleri tek tek dökülür, küçük boyutlu, ekvatoral görünümde sıklıkla sferoidal şekilli, genellikle hekzakolpat ve mikroekinat-perforat ekzin süsüne sahiptir.
\end{abstract}

Anahtar kelimeler: Rubia, vejetatif anatomi, polen morfolojisi, mikroskobi tekniği.

\section{Introduction}

Rubiaceae (coffee family) is the fourth largest family of angiosperms with about 660 genera and 12000 species assigned into 42 tribes (Ehrendorfer, Barfuss, Manen, \& Schneeweiss, 2018). Rubia L., the type genus for the Rubiaceae in the order Gentianales, possesses an Old World distribution (Yang, Sun, Ehrendorfer, \& Nie, 2016). Rubia is the third largest genus of tribe Rubieae in the Rubiaceae with about 80 species around the world (Yang, Sun, Ehrendorfer, \& Nie, 2016). Approximately half of these species are found in China, making it the most significant diversity center of this genus (Yang, Sun, Ehrendorfer, \& Nie, 2016). The genus is distinguished from other members of this tribe by its 5-lobed corolla and fleshy fruits (Manen, Natali, \& Ehrendorfer, 1994). Rubia species have been used for their red dyes known as alizarin in textiles, carpets, and other objects (e.g., R. tinctorum L., $R$. cordifolia L. roots). In addition to the commercial value, roots of Rubia species (e.g., R. yunnanensis Diels, R. akane Nakai) are medicinally used for the treatment of cancers, tuberculosis, rheumatism, hematemesis, metrorrhagia, epistaxis, contusion, and menoxenia in the Chinese folk medicine and healing wounds, inflammation, skin infections in the Indian traditional medicine (Meena, Pal, Panda, Sannd, \& Rao, 2010; Zhao et al., 2011; Mouri, \& Laursen, 2012).

In Turkey, five species of Rubia grow naturally: $R$. davisiana Ehrend. (endemic), R. peregrina L., Rubia rotundifolia Banks \& Sol., $R$. tenuifolia d'Urv. and $R$. tinctorum $\mathrm{L}$. The most significant and stable morphological feature for infrageneric classification of the genus are the leaf venation pattern. Sect. Rubia s.l. has single and pinnate veins whereas there are palmate major veins, branching from the leaf basis in sect. Oligoneura Pojark. Except for $R$. davisiana in sect. Oligoneura, the other Turkish Rubia species are classified in sect. Rubia s.l. There are some studies on the anatomy of some genera of Rubiaceae, as in Alseis (e.g., Campbell, Rabelo, \& da Cunha, 2016), Bathysa (e.g., Nascimento, Gomes, \& Vieira, 1996), Psychotria (e.g., Marques et al., 2015), Rondeletia (e.g., Kocsis, Darók, J., \& Borhidi, 2004), Rudgea (e.g., Leo, Mantovani, \& Vieira, 1997), Rustia (e.g., Vieira, Delprete, Leitão, \& Leitão, 2001), 
Simira (e.g., Moraes, Barros, Silva Neto, Gomes, \& Da Cunha, 2009), and Virectaria (e.g., Dessein, Jansen, Huysmans, Robbrecht, \& Smets, 2001), as well as the pollen morphology of some species of Rubiaceae (Huysmans, Robbrecht, \& Smets, E., 1994, 1998; Huysmans, Robbrecht, Delprete, \& Smets, 1999; Piesschaert, Huysmans, Jaimes, Robbrecht, \& Smets, E., 2000; Dessein, Scheltens, Huysmans, Robbrecht, \& Smets, 2000; Dessein, Huysmans, Robbrecht, \& Smets, 2002; Huysmans, Dessein, Smets, \& Robbrecht, 2003). However, previously published accounts on the anatomy and palynology of Rubia are limited to general studies. Recent works on the anatomy and pollen morphology of almost all Rubia species are not available. Here, the study presents detailed anatomical characteristics of $R$. tinctorum for the first time. Some palynological properties of $R$. tinctorum from Belgium and $R$. peregrina from France are described (Huysmans, Dessein, Smets, \& Robbrecht, 2003). However, in this work, new information about the pollen morphology of $R$. tinctorum growing in Turkey is provided. The main goal of the present study is to describe the stem and leaf anatomy and the palynology of $R$. tinctorum.

\section{Material and Methods}

Specimens of $R$. tinctorum were collected from its natural habitats during field studies in Usak and Kutahya provinces in Turkey. Sample details are provided in the following: Usak: Kasaboglu stream, June 2017, N. Ar1 15, Usak: near Derbent village, July 2017, N. Arı 20, Kutahya: New Gediz road, roadsides, July 2017, N. Ar1 23. The collected specimens were kept at the Laboratory of Plant Systematics and Phylogenetics at Usak University.

\subsection{Light microscopy (LM) studies}

A variety of methodologies exist for preparing plant organs for anatomical studies, many of which are sample dependent (e.g., Johansen, 1940; Keating, 2014). Here, for obtaining anatomical features of seven to ten stems and leaf specimens per population, material kept in $70 \%$ ethyl alcohol was prepared and analyzed using traditional paraffin wax-embedding protocols with some modifications. They were embedded into paraffin, sliced into thin transverse sections with a thickness ranging from 8 from $15 \mu \mathrm{m}$, stained based on a double staining protocol using safranin and fast green, and then mounted in Entellan. Anatomical observations were performed on twenty-five slides.

For palynological studies, the technique of Wodehouse (1935) was used so as to retain the natural form of pollen grains. After the grains were treated with $70 \%$ ethyl alcohol for the removal of oily substances, they were mounted in glycerin jelly stained with basic fuchsin. For species in monads, at least 30 pollen grains per sample were examined in equatorial and polar views. Polar axis $(\mathrm{P})$, equatorial axis $(\mathrm{E})$, colpus length $(\mathrm{Clg})$, colpus width (Clt), exine thickness (Ex), intine thickness (In), and mesocolpium diameter (Me) were measured. Each value was expressed as mean \pm standard deviation.

For LM studies, anatomical and palynological material was examined and photographed by a Leica DM1000 light microscope (Leica Microsystems, Wetzlar,
Germany) at the Laboratory of Plant Systematics and Phylogenetics at Usak University.

\subsection{Scanning electron microscopy (SEM) studies}

For SEM investigations, the material was placed on aluminum stubs covered with carbon tape and sputtercoated with gold-palladium for five minutes. Then, the pollen grains were examined to determine the exine sculpturing at magnifications ranging from $\times 10000$ to $\times 20000$ with using a LEO-1430 VP SEM (Carl Zeiss SMT, Oberkochen, Germany) at an accelerating voltage of $20 \mathrm{kV}$ at the Technology Application and Research Centre (TUAM), Afyon Kocatepe University, Afyonkarahisar, Turkey. The palynological terminology of Halbritter et al. (2019) was followed.

\section{Results and Discussion}

\subsection{Stem anatomy (Fig. 1A-D).}

The outermost layer of the root is covered by epidermal cells. Underneath the epidermis, the cortex comprises of multilayered parenchyma cells with thin walls. Vascular tissues ise arranged in collateral vascular bundles. Vessel outline is angular or almost rounded. Rays are 1(-2)seriate. In the central pith, the broken cells partially form a cavity. The peripheral limit of the pith cavity is lined with several layers of polygonal, thin-walled parenchyma cells with intercellular spaces. The stem anatomical properties of $R$. tinctorum are consistent with previous studies (e.g. Metcalfe, \& Chalk, 1950).

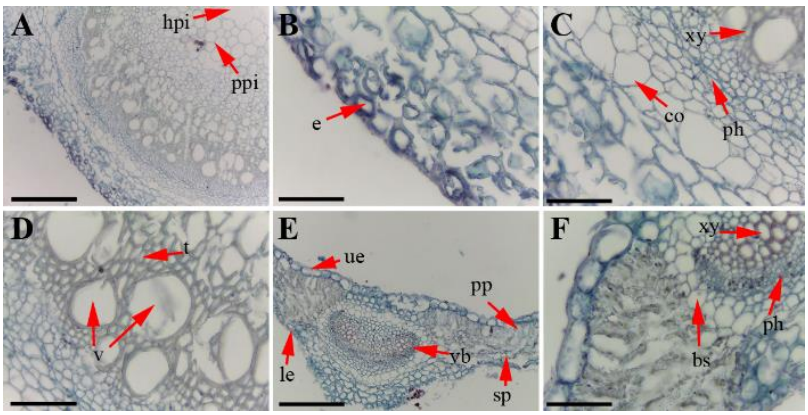

Figure 1. LM micrographs of cross-sections of $R$. tinctorum stems (A-D) and leaves (E-F). Abbreviations: bs: bundle sheath, co: cortex, e: epidermis, hpi: hollow pith cavity, le: lower epidermis, pp: palisade parenchyma, ph: phloem, ppi: parenchymatous pith cells, sp: spongy parenchyma, t: trachea, ue: upper epidermis, $v$ : vessels, vb: vascular bundle, xy: xylem. Scale bars $=(A, E) 200 \mu \mathrm{m}$, (B, C, D, F) $50 \mu \mathrm{m}$.

\subsection{Leaf anatomy (Fig. 1E-F).}

The leaf epidermis is one layered elongated to isodiametric cells covered with a fine cuticle. The upper epidermal cells are larger than the lower epidermal ones. The leaf is bifacial and amphistomatic. Stomata are placed slightly above the epidermal cells. The mesophyll is dorsiventral and comprises one layer of columnar palisade parenchyma cells and a few layers of irregularly organized spongy parenchyma cells. The presence of the dorsiventral mesophyll is congruent with the leaf properties for the family Rubiaceae (Metcalfe, \& Chalk, 1950; Robbrecht, 1988). The midrib consists of a large collateral vascular bundle surrounded by parenchymatous bundle sheath cells. The vascular tissue in $R$. tinctorum shows a collateral arrangement described previously in other Rubiaceae species (Robbrecht, 1988). Bundle sheath extensions 
surround the vascular tissue. The bundle sheath extending until the adaxial and abaxial epidermis is reported in some species of Rubiaceae (Dickison, 2000). These extensions can provide an additional mechanical support for the leaf (Moraes, Barros, Silva Neto, Gomes, \& Da Cunha, 2009).

\subsection{Pollen morphology (Fig. 2).}

The pollen grains of $R$. tinctorum are shed as monads. Rubiaceae pollen grains are mostly dispersed as monads however permanent tetrads in some species (Dessein et al., 2005). Pollen size $R$. tinctorum is small as $P=15.45-19.75$ $(17.32 \pm 1.03) \mu \mathrm{m}$ and $\mathrm{E}=16.23-23.18(19.17 \pm 1.42) \mu \mathrm{m}$. Pollen size of Rubiaceae varies from small to very large; however, many species have small to medium pollen grains ranging from 20 to $40 \mu \mathrm{m}$. (Dessein et al., 2005). In this study, the pollen shape of $R$. tinctorum is more or less circular in polar view while it is mainly spheroidal (very rarely suboblate) in equatorial view $(\mathrm{P} / \mathrm{E}=0.85-0.95)$. The pollen grains are isopolar, radially symmetrical, and mostly hexacolpate (occasionally pentacolpate, heptacolpate, or octacolpate). In a palynological study on Northwest European representatives of several genera of Rubiaceae (Huysmans, Dessein, Smets, \& Robbrecht, 2003), findings concerning $R$. tinctorum pollen grains relatively confirm results of our study. However, our findings represent some differences in pollen size and the number of aperture. In this previous work, its pollen grains were found as $\mathrm{P}=19-22$ (20.5) and $\mathrm{E}=18-22$ (21) $\mu \mathrm{m}$ in size and spheroidal shape $(\mathrm{P} / \mathrm{E})$ and hexacopate to octacolpate. The differences in size and shape can be assumed to be mainly due to variations in preparation. In the present study, pentacolpate pollen grains of $R$. tinctorum are first recorded. Colpi are distributed symmetrically. Colpus length is 9.63-14.98 (11.93 \pm 1.60$)$ $\mu \mathrm{m}$ and colpus width is 1.95-4.20 (2.99 \pm 0.47$) \mu \mathrm{m}$. Mesocolpium is 4.21-7.32 (5.67 \pm 0.64$) \mu \mathrm{m}$. Exine and intine layers are 0.45-0.91 (0.65 \pm 0.12$)$ and 0.23-0.48 (0.31 \pm 0.06$)$ $\mu \mathrm{m}$ in thickness, respectively. SEM investigations show microechinate-perforate surface ornamentation pattern (perforate with microspines).

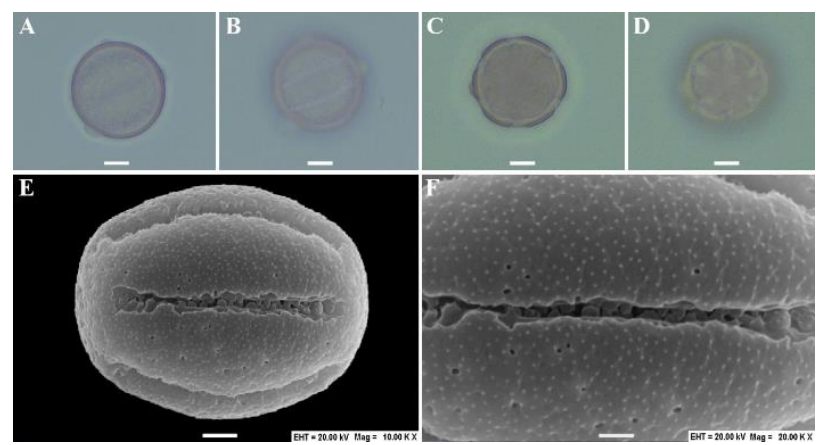

Figure 2. LM (A-D) and SEM (E-F) micrographs of R. tinctorum pollen grains. (A-B) Pollen grains in equatorial view, (C-D) Hexacolpate pollen grains in polar view, (E) Pollen grain in equatorial view, (F) Close-up showing microechinate-perforate surface sculpture and apertural region of pollen. Scale bars $=(\mathrm{A}$ D) $5 \mu \mathrm{m},(\mathrm{E}) 2 \mu \mathrm{m},(\mathrm{F}) 1 \mu \mathrm{m}$,

The present paper is a preliminary study on anatomy and palynology of Turkish species of the genus Rubia. The results contribute to palynological knowledge of Rubia species distributed in Turkey. The combination of anatomical and palynological aspects may be valuable in the systematic of the genus Rubia. However, it is necessary to conduct further studies to obtain more comparative information about anatomy and pollen morphology of other Rubia species.

Acknowledgements: This study is a part of the M.Sc. dissertation of the first author at Department of Molecular Biology and Genetics at the Institute of Natural and Applied Sciences, Usak University, Usak, Turkey. Partial financial support for this study was supported by a scientific research project UBAP-2017/MF012 from the Scientific Research Projects Coordination Unit of Usak University. We thank Mr. Samet Abbak at The Technology Application and Research Centre (TUAM), Afyon Kocatepe University, Afyonkarahisar, Turkey for operating the SEM. We also thank three anonymous reviewers for their comments that improved the manuscript.

\section{References}

Campbell, G., Rabelo, G.R., \& da Cunha M. (2016). Ecological significance of wood anatomy of Alseis pickelii Pilg. \& Schmale (Rubiaceae) in a Tropical Dry Forest. Acta Botanica Brasilica, 124-130. https://doi.org/10.1590/0102-33062015abb0267

Dessein, S., Scheltens, A., Huysmans, S., Robbrecht, E., \& Smets, E. (2000) Pollen morphological survey of Pentas (Rubiaceae-Rubioideae) and its closest allies. Review of Palaeobotany and Palynology, 112, 189-205. https://doi.org/10.1016/S0034-6667(00)00041-5

Dessein, S., Jansen, S., Huysmans, S., Robbrecht, E., \& Smets, E. (2001). A morphological and anatomical survey of Virectaria (African Rubiaceae), with a discussion of its taxonomic position. Botanical Journal of the Linnean Society, 137(1), 1-29. https://doi.org/10.1111/i.10958339.2001.tb01102.x

Dessein, S., Huysmans, S., Robbrecht, E., \& Smets, E. (2002). Pollen of African Spermacoce species (Rubiaceae) Morphology and evolutionary aspects. Grana, 41, 69-89. https://doi.org/10.1080/001731302760156882

Dessein, S., Ochoterena, H., De Block, P., Lens, F., Robbrecht, E., Schols, P., Smets, E., Vinckier, S., \& Huysmans, S. (2005). Palynological characters and their phylogenetic signal in Rubiaceae. The Botanical Review, 71, 354414. 8101(2005)071[0354:PCATPS]2.0.CO;2

Dickison, W.C. (2000). Integrative Plant Anatomy. San Diego, Harcourt Academic Press., 533 pp.

Ehrendorfer, F., Barfuss, M.H.J., Manen, J.-F., \& Schneeweiss, G.M. (2018). Phylogeny, character evolution and spatiotemporal diversification of the species-rich and world-wide distributed tribe Rubieae (Rubiaceae) $\begin{array}{llll}P L O S & \text { ONE, 13(12), } & & \\ \end{array}$ https://doi.org/10.1371/journal.pone.0207615

Halbritter, H., Ulrich, S., Grímsson, F., Weber, M, Zetter, R., Hesse, M., Buchner, R., Svojtka, \& M., Frosch-Radivo, R. (2018). Illustrated Pollen Terminology (2nd ed.). Switzerland: Springer Open, 483 pp.

Huysmans, S., Robbrecht, E., \& Smets, E. (1994). Are the genera Hallea and Mitragyna (Rubiaceae-Coptosapelteae) pollen morphologically distinct?. Blumea, 39, 321-340

Huysmans, S., Robbrecht, E., \& Smets, E. (1998). A collapsed tribe revisited: pollen morphology of the Isertieae (Cinchonoideae-Rubiaceae). Review of Palaeobotany and Palynology, 104, 85-113. https://doi.org/10.1016/S0034-6667(98)00054-2

Huysmans, S., Robbrecht, E., Delprete, P., \& Smets, E. (1999). Pollen morphological support for the Catesbaeeae-Chiococceae-Exostemacomplex (Rubiaceae). Grana, 38, 325-338.

Huysmans, S., Dessein, S., Smets, E., \& Robbrecht, E. (2003). Pollen morphology of NW European representatives confirms monophyly of Rubieae (Rubiaceae). Review of Palaeobotany and Palynology, 127, 219-240. https://doi.org/10.1016/S0034-6667(03)00121-0

Johansen, D.E. (1940). Plant Microtechnique. New York, USA, McGraw-Hill Book Company, 523 pp.

Keating, R. (2014). Preparing Plant Tissue for Light Microscope Study: A Compendium of Simple Techniques. St. Louis, Missouri, USA., Missouri Botanical Garden Press, 155 pp.

Kocsis, M., Darók, J., \& Borhidi, A. (2004). Comparative leaf anatomy and morphology of some neotropical Rondeletia (Rubiaceae) species. Plant Systematics and Evolution, 248: 205-218. https://doi.org/10.1007/s00606-002-0144-0

Leo, R.R.T., Mantovani, A., \& Vieira, R.C. (1997). Anatomia foliar de Rudgea ovalis Müll. Arg. e R. tinguana Müll. Arg. (Rubiaceae). Leandra, 12, 33-44.

Manen, J.F., Natali, A., \& Ehrendorfer, F. (1994). Phylogeny of RubiaceaeRubieae inferred from the sequence of a cpDNA intergene region. Plant 
Systematics and Evolution, 190, 195-211. https://doi.org/10.1007/BF00986193

Marques, J.B.C., Callado, C.H., Rabelo, G.R., Silva Neto, S.J., \& Da Cunha M. (2015). Comparative wood anatomy of Psychotria L. (Rubiaceae) Species in Atlantic Rainforest remnants at Rio de Janeiro state. Brazil. Acta Botanica Brasilica, 29, 433-444. http://dx.doi.org/10.1590/S010233062011000100021

Meena, A.K., Pal, B., Panda, P., Sannd, R., Rao, M.M. (2010). A review on Rubia cordifolia: its phyto constituents and therapeutic uses. Drug Invention Today, 2(5), 244-246.

Metcalfe, C.R., \& Chalk, L. (1950). Anatomy of Dicotyledons - Leaves, Stem and Wood in Relation to Taxonomy with Notes on Economic Uses. Oxford, Clarendon Press., 806 pp.

Moraes, T.M.S., Barros, C.F., Silva Neto, S.J., Gomes, V.M., \& Da Cunha, M. (2009). Leaf blade anatomy and ultrastructure of six Simira species (Rubiaceae) from the Atlantic Rain Forest, Brazil. BioCell, 33(3), 155-165.

Mouri, C., \& Laursen, R. (2012). Identification of anthraquinone markers for distinguishing Rubia species in madder-dyed textiles by HPLC. Microchimica Acta, 179, 105-113. https://doi.org/10.1007/s00604-012$\underline{0868-4}$

Nascimento, M.V.O., Gomes, D.M.S., \& Vieira, R.C. (1996). Anatomia foliar de Bathysa stipulata (Vell.) Presl. (Rubiaceae). Revista Unimar, 18(2), 387401.

Piesschaert, F., Huysmans, S., Jaimes, I., Robbrecht, E., \& Smets, E. (2000). Morphological evidence for an extended tribe Coccocypseleae (Rubiaceae-Rubioideae). Plant Biology, 2, 536-546. https://doi.org/10.1055/s-2000-7473

Robbrecht, E. (1988). Tropical woody Rubiaceae. Characteristic features and progressions. Contributions to a new subfamilial classification. Opera Botanica Belgica, 1, 1-271.

Vieira, R.C., Delprete, P.G., Leitão, G.G., \& Leitão, S.G. (2001). Anatomical and chemical analyses of leaf secretory cavities of Rustia formosa (Rubiaceae). American Journal of Botany, 88, 2151-2156. https://doi.org/10.2307/3558376

Wodehouse, R.P. (1935). Pollen Grains. New York, Mc Graw-Hill Press.

Yang, L.L., Sun, H., Ehrendorfer, F., \& Nie, Z.L. (2016). Molecular phylogeny of Chinese Rubia (Rubiaceae: Rubieae) inferred from nuclear and plastid DNA sequences. Journal of Systematics and Evolution, 54(1), 37-47. https://doi.org/10.1111/jse.12157

Zhao, S.M., Kuang, B., Fan, J.T., Yan, H., Xu, W.Y., Tan, N.H. (2011). Antitumor cyclic hexapeptides from Rubia plants: history, chemistry, and mechanism (2005-2011). Chimia International Journal for Chemistry, 65(12), 952-956. https://doi.org/10.2533/chimia.2011.952 